\title{
Diversity and distribution of microfungi in foliage leaf, bark and leaf litter of Couroupita guianensis
}

\author{
G. Venkatesan*, P. S. Sharavanan \\ PG and Research Department of Botany, Mannai Rajagopalaswami Government Arts College, Mannargudi - 614001, \\ Tamil Nadu, India
}

Received: June 18, 2020

Revised: November 27, 2020

Accepted: December 04, 2020

Published: December 18, 2020

*Corresponding Author:

G. Venkatesan,

E-mail:gv2032@gmail.com

\section{ABSTRACT}

The diversity and distribution of micro fungal assemblages in the foliage leaf, bark and leaf litter tissues of the sacred plant, Couroupita guianensis. For the host, we recorded 1005 fungal species isolates from 900 tissue segments. A total of 62 fungal species were isolated from foliar endophytes, phellophytes and leaf litter. The colonization frequency of the fungi species has been recorded as $111.66 \%$ from the endophytes, phellophytes and leaf tissues. The fungi species recovered in various groups included ascomycetes, coelomycetes, hyphomycetes, zygomycetes and sterile fungi. The number of fungal species is increased for the plant tissues, it showed that the species diversity is increasing. A correspondence analysis also showed that the fungal species assemblages were different from each type of tissue.

KEYWORDS: Couroupita guianensis, endophytes, phellophytes, litter fungi, sacred, tissue specificity

\section{INTRODUCTION}

Endophytes are microorganisms that live within plant tissues without causing symptoms of the disease. Plant-associated fungi are usually divided into a different ecological group based on mycorrhizal, pathogenic, epiphytic, endophytic, and saprotrophic fungi. Most studies focus on only one of these groups, and very few consider interactions among them or between fungi and bacteria. In the investigation, Couroupita guianensis is being investigated for the approaches to study plant-associated fungal microbes' communities. Endophytes are microorganism live in within plants without causing any harm to their growth and development. Unlike disease-causing microorganisms, endophytes are non-pat pathogenic and many of them are known to enhance their plant host's fitness [1]. Fungal endophytes colonize living plant tissues without producing any apparent symptoms or obvious negative effects [2]. The term endophyte was coined by de Bary [3] to denote organisms that colonize internal plant tissues. The distribution pattern of endophytes is influenced by various factors. Among the endophytic fungi are well-known in tree leaves [4] geographically varied. Fungi play key roles in ecosystems as decomposers, mutualists and pathogens, while in most cases, the role of individual fungus in nature is still unknown [5]. Phellophytes of some temperate trees [6] and a few tropical angiosperms [7,8] have been studied. In bark tissues, however, whether these factors affect the community of endophytic fungi is unknown. Fungi, as associates of higher plants in the form of mycorrhizae, endophytes and pathogens, and as decomposers of plant litter, play a crucial role in structuring and maintaining plant communities $[9,10]$. The fungal kingdom is species diversity, and fungi perform an abundance of functions in ecosystems, yet the extent of fungal diversity is faulty known. Fungi play an indispensable role in the decomposition of plant substrates in various ecosystems $[11,12]$. The fungal diversity in decaying plant matter has previously been studied in tropical and temperate regions [13]. The tropical and sub-tropical rainforest is most rich in plant diversity, so the endophytic diversity in this region has been studied $[14,15]$. Each plant harboured at least one or more fungal endophytes, thus fungal endophytes have high biodiversity. It has been estimated that all the plant, animal or microbial species would be described in about 30-90 years before they became extinct, considering that there are probably $1.5-3$ million undescribed species on the earth with an extinction rate of $0.01-1 \%$ (at most $5 \%$ ) every decade [16]. In contrast, an updated estimate of fungal diversity showed that the fungal species ranged from 2.2 to 3.8 million worldwide [17]. Although there are reports from the tropics regarding the fungal diversity, distribution, and contribution to the global fungal taxa of a few ecological groups of fungi such as leaf litter fungi [18], endophytes [19,20]. A few studies in the tropics that compare these aspects of different ecological groups of fungi associated with plant communities [21]. The aim of our

Copyright: (C) The authors. This article is open access and licensed under the terms of the Creative Commons Attribution License (http://creativecommons.org/licenses/by/4.0/) which permits unrestricted, use, distribution and reproduction in any medium, or format for any purpose, even commercially provided the work is properly cited. Attribution - You must give appropriate credit, provide a link to the license, and indicate if changes were made. 
study was to compare a single host of the fungal species diversity of endophytes(leaf), phellophytes(bark) and litter(leaf litter) ecology niche groups of fungi and to illuminate their possible association in fungal diversity records.

\section{MATERIALS AND METHODS}

\section{Plant Description and Sample Collection}

Cannonball tree is one of the most striking examples of cauliflory is Couroupita guianensis. It belongs to the family Lecythidaceae. The species finds the habitat in almost all tropical and sub-tropical regions of the world with the greatest abundance in Amazonian. In India, it is also grown as an ornamental and sacred species (Fig.1). The plant was collected from Mannargudi, Tamil Nadu; South India was studied for the fungal association. It's located at $10.67^{\circ} \mathrm{N} 79.43^{\circ} \mathrm{E}$ in the Delta district from collected for studying. Three trees species from Mannargudi area in Tamilnadu state were collected. Sixty-one mature, healthy leaves were collected from three individuals of each host species ( $20 \pm 25$ from each individual) and screened for endophytes during winter (raining season - June to October 2019) season. The leaf and bark samples were brought to the laboratory in sterile polythene bags and processed within 24 hours of collection. Litters sample was collected after the raining season (October to November 2019), when the leaves fall down. This continued to investigate the autumn season at the start of decomposition of the leaf.

\section{Sterilization of Plant Materials}

Healthy foliar leaves from selected plant material were washed thoroughly in running water and three segments of $0.5 \mathrm{~cm}^{2}$ were cut from the midrib/lamina portion of each leaf. All segments were surface sterilized in $70 \%$ ethanol for 5 secs, followed by $4 \%$ $\mathrm{NaOCI}$ for 90 secs then they were washed in sterile water for 10 secs [22]. For bark cut into $0.5 \mathrm{~cm} 2$ segments and surface sterilized by dipping in $75 \%$ ethanol for the $60 \mathrm{~s}$, immersed in $4 \%$ $\mathrm{NaOCl}$ for 180s, and finally dipped in 75\% ethanol for 30s [23]. A total of 150 leaves and bark segments were screened for the presence of leaves and bark fungi.
For litter, mature brown leaves without any symptoms of decay were collected from the plant floor beneath the tree, brought to the laboratory in sterile polythene bags, and processed within $24 \mathrm{~h}$ of collection. From each leaf lamina, 5 segments (approx. $0.5 \mathrm{~cm}^{2}$ each) were cut. These segments were washed in sterile distilled water, and 150 segments were randomly selected and incubated in sterile Petri dishes lined with sterile moist filter papers. Ten segments each were placed in a Petri dish. These segments were observed by direct microscopic observation, and the fruiting structures and spores of fungi were isolated and identified [24].

\section{Statistical Analyses}

The colonization frequency (CF\%) of an endophyte/phellophyte fungal species was calculated [25]. Fisher's $\alpha$ was used to estimate species diversity since it is a better discriminator and is not unduly affected by the abundance of the most common species [26]. The Correspondence Analysis and the Bray-Curtis measure of distance were calculated [27]. The density of colonization and isolation frequency was calculated as follows. Isolation frequency $(\mathrm{IF} \%)=$ Total number of isolates in particular species/Total number of segments x 100 . Relative Percentage of Occurrence (RPO) of each group (viz. Ascomycetes, Coelomycetes, Hyphomycetes, Zygomycetes and sterile forms) of fungal species in each plant species was calculated as follows. RPO $=$ Total colonization frequency of one group /Total colonization frequency for all the Groups of fungi $x 100$.

\section{RESULTS AND DISCUSSION}

We had an investigation of the Couroupita guianensis plant as a precursor of the diversity of fungi in various tissues, the diversity of fungi in endophytes in leaves, phellophytes in the bark and leaf-litter saprophytic fungi. Although, based on the results of the recovered fungal species of this plant, it is described as follows. A total of 467 isolates belonging to 22 fungal species were isolated as endophytes and 346 isolates belonging to 29 fungal species were isolated from bark tissues (phellophytes) and 192 isolates belonging to 52 fungal species were isolated as leaf litter from this plant of C. guianensis,

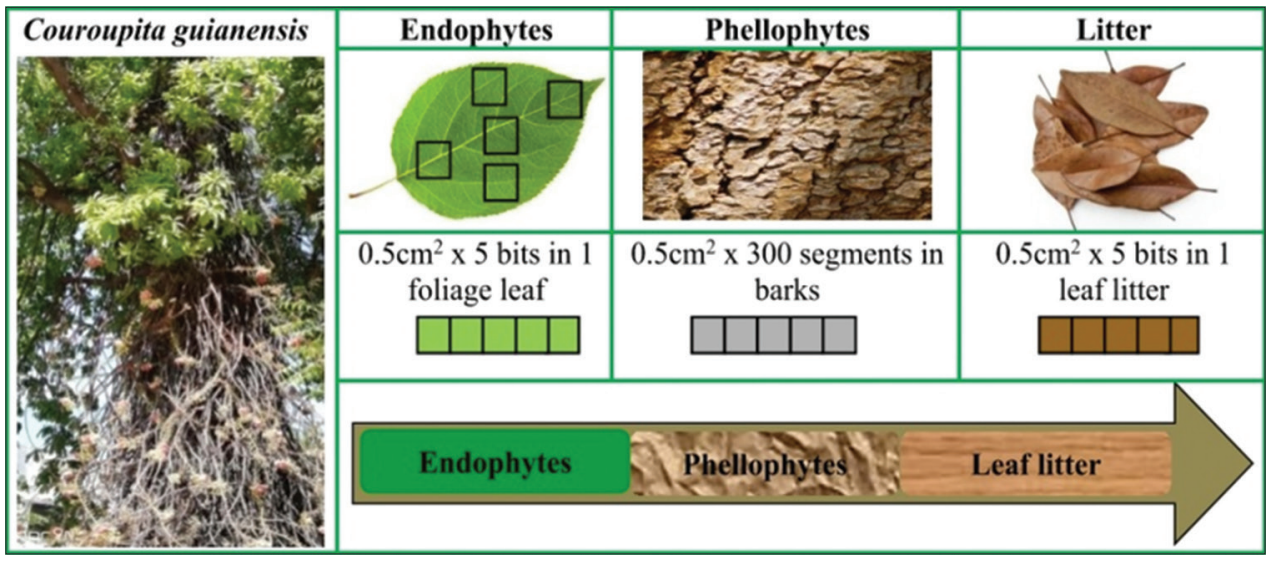

Figure 1: A view of Couroupita guianensis plant and schematic strategy for isolating fungi 
respectively. For the plant, we recorded 1005 fungal species from 900 segments (leaf, bark, and leaf litter/300 segments each) (Table 1). A total of 22 fungal species were isolated from 300 leaf segments incubated from C. guianensis plant. These fungi belonged to Ascomycetes (18.18\%), Coelomycetes (27.2\%), Hyphomycetes (40.9\%), and sterile forms (13.6\%) (Table 1). Phomopsis species is dominant and Colletotrichum sp. Sporormiella sp, Phyllostica capitalists, and Xylariaceous form were the most frequently isolated. Twenty- nine fungal species were isolated from 300 bark segments. These bark fungi were dissimilar from leaf tissues. A total of 29 species among 17.24\% in Ascomycetes, 20.68\% in Coelomycetes, $62.06 \%$ in Hyphomycetes fungal group were isolated from bark tissue. Lasiodiplodia theobromae is a species dominated in the bark and Phomopsis sp., Colletotrichum sp., Sporormiella sp, Phyllostica capitalists, Xylariaceous form, Chaetomella sp., Alternaria sp., Aspergillus sp., Fusarium spp., Nigrospora sp., had most frequently isolated. A few species similar to the leaf endophytes were frequently isolated. A total of 52 fungal species were recovered from 300 leaf litters. These saprophytic fungal species belonging to $9.61 \%$ ascomycetes, $9.61 \%$ coelomycetes, $75.0 \%$ hyphomycetes, $5.76 \%$ zygomycetes are recorded (Table 1 and Fig 2). Most of the species were isolated in fewer colonies or spores only. It may not be colonized in decomposed tissues, hence it will not be isolated colonies. It has occurred only in spore stages. Table 1 are described the details of each isolated and identified taxon of the fungal isolates in various tissues from C. guianensis (Table 1). A total colonization frequency $(\mathrm{CF} \%)$ has been dissimilar significantly among the leaf endophytes, bark fungi, and leaf litter fungi in C. guianensis plant, these fungal ranged from $64 \%$ in the leaves tissue, $87 \%$ in the bark tissues, and $64 \%$ leaf litter fungi. Though, as $90 \%$ of CF (\%) was recorded in high diversity in a total of 900 segments. This fungal diversity is isolated in live and dead tissues of a single host although considerable has high diversity (Table 1). A few fungi species which failed to sporulate were designated as "mycelia sterile". They can be identified later with different incubation such as sporulation in UV, so for colony characteristics, the mycelia were transferred into PDA agar media.

This enlists some genera Colletotrichum, Phomopsis and Phyllosticta are ubiquitous endophytes and have been reported from most plant hosts [28,29] and they are globally dominant in which Colletotrichum sp, Phyllosticta sp. is the most frequently encountered endophytic fungi [30] that may be either host-specific or generalist [31] and the remaining genera such as Cladosporium in Azadirachta

Table 1: Number of species, isolates, and diversity of the endophytes, phellophytes and leaf litter fungi from the Couroupita guianensis

\begin{tabular}{|c|c|c|c|c|c|}
\hline SI.No. & & Endophytes & Phellophytes & Litter & Total \\
\hline 1 & Total no. of fungal species & 22 & 29 & 52 & 62 \\
\hline 2 & Total no. of colonies isolates & 467 & 346 & 192 & 1005 \\
\hline 3 & Total no. of segments & 300 & 300 & 300 & 900 \\
\hline 4 & Colonization Frequency (CF \%) & 155.66 & 115.33 & 64.0 & 111.66 \\
\hline 5 & RI(Margalef's) & 3.41 & 4.78 & 9.70 & 8.82 \\
\hline 6 & $\mathrm{H}^{\prime}$ (Shannon Index) & 1.8 & 3.08 & 3.56 & 3.03 \\
\hline 7 & Fisher's alpha & 4.79 & 7.53 & 23.44 & 14.60 \\
\hline \multirow[t]{6}{*}{8} & Relative Percentage of Occurrence & roup of funga & & & \\
\hline & Ascomycetes & 18.18 & 17.24 & 9.61 & 11.29 \\
\hline & Ceolomycetes & 27.2 & 20.68 & 9.61 & 9.67 \\
\hline & Hyphomycetes & 40.9 & 62.06 & 75.0 & 69.35 \\
\hline & Zygomycetes & 0.0 & 0.0 & 5.76 & 4.8 \\
\hline & Sterile forms & 13.6 & 0.0 & 0.0 & 4.8 \\
\hline
\end{tabular}

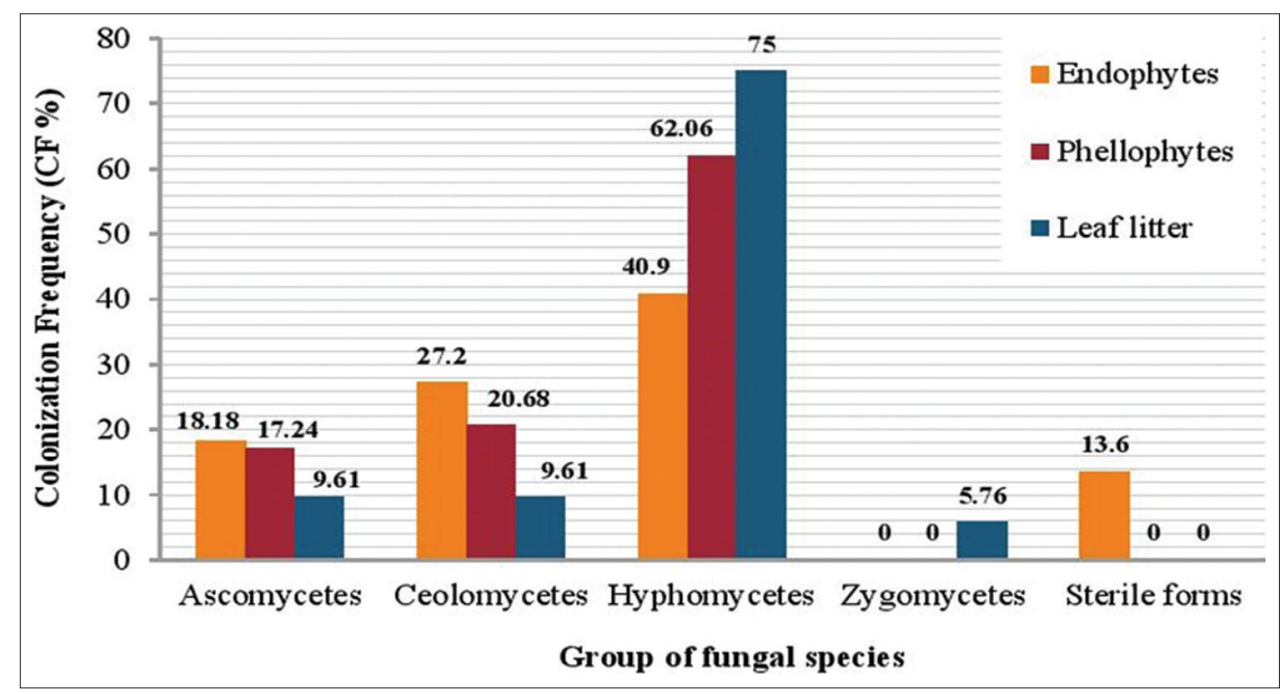

Figure 2: Relative Percentage Occurrence (RPO) of the endophytes, phellophytes and leaf litter fungi from the Couroupita guianensis 


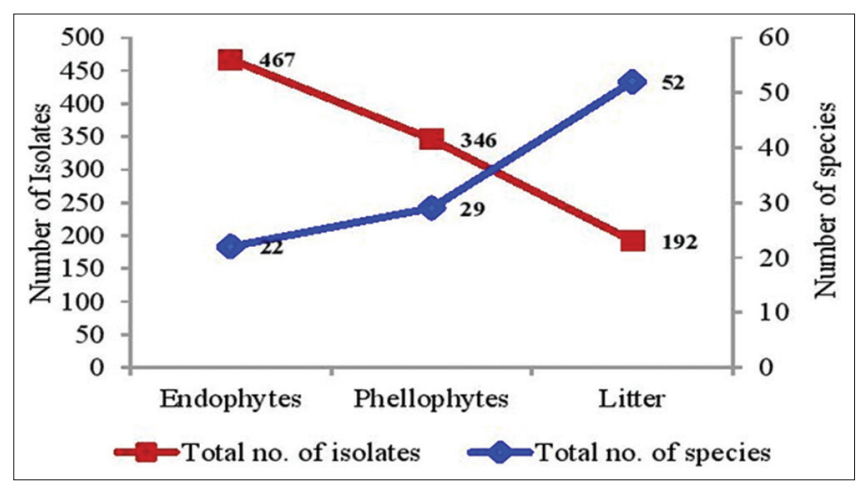

Figure 3: No. of fungal species and colonies isolated for the endophytes, phellophytes and leaf litter fungi from the Couroupita guianensis

indica [32], Fusarium in Murraya koenigii [33], Ocimum sanctum $[34,35]$ was also reported as ubiquitous endophytes. Some coelomycetes such as Colletotrichum sp, Pestalotiopsis sp. Phomopsis sp and Phyllosticta sp. are routinely isolated as endophytes [36]. In addition, a few phylloplane fungi including Alternaria, Aureobasidium, and Cladosporium are regularly isolated as endophytes. Intriguingly, some coprophilous genera (Chaetomium, Sordaria, Sporormiella, etc.,) have been reported as endophytes from several hosts [37]. Fungal species could grow to continue from alive tissues to dead tissues, so fungi could be occupied in the bark tissues. Although these mycelia or spores had such fungi a structure, they had assemblages alive in dead tissues' structure and other dormant structures not clear of such fungi. An early study for bark fungi has been reported in a tropical forest [38]. In the study of fungal diversity in Couroupita guianensis, 52 saprophytic fungi in leaf litters, 29 phellophytes in the bark tissues and 22 endophytes in foliar tissues were recovered (Table 1); While, dissimilar fungal colonization had occurred from these kinds of tissues, as 467 colonizes in leaf tissues, 346 colonizes in bark tissues, and 192 fungi colonize in leaf litter (Table 1). Hyphomycetes were the abundant group of fungi followed by Coelomycetes Ascomycetes and sterile forms in all kind of tissues (Table 1 and Fig. 2). The species richness or the abundance of the species diversity index (Fisher's alpha) of the entire fungal assemblage of these plant tissues was 14.60. The species richness of fungal assemblage of endophytes in 4.79, phellophytes assemblage was 7.53 and leaf litters in 23.44 were found (Table 1). Although, as the results have shown, the assemblage of the (richness) fungal species might diversity in leaf litter than the endophyte, phellophyte (Table 1 and Fig. 3). Moreover, the richness index (R l) and evenness index (H l) has been similar to the results (Table 1). Correspondence analysis revealed that endophytes, phellophytes and leaf litter fungi assemblages the tree's tissues into three distinct clusters (Fig. 4). The study in various ecological groups of fungi brings to being associated with different tissues of a single tree. Also, such a survey would identify degrees of host restriction, a critical factor in the evaluation of biodiversity. Tissue specificity fungi among endophytes, phellophytes and leaf litter have been consequently diverse to increase.

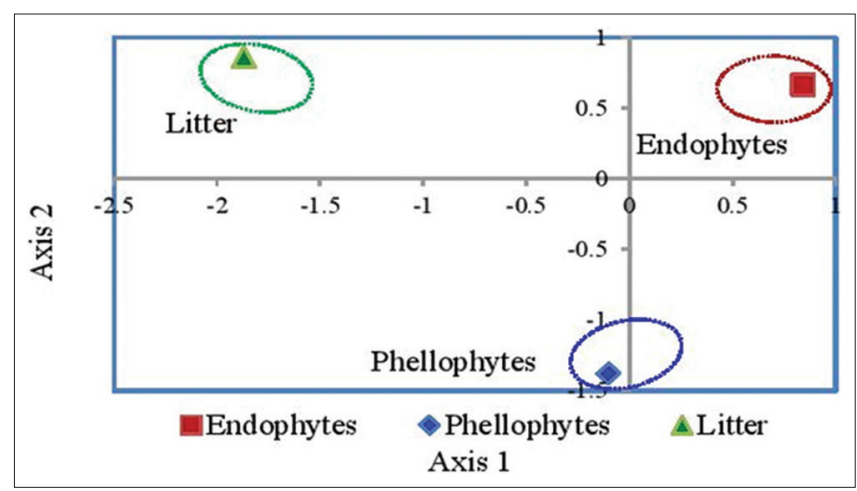

Figure 4: Correspondence analyses for the endophytes, phellophytes and leaf litter fungi assemblages of the Couroupita guianensis

\section{CONCLUSIONS}

In the endophyte, phellophyte and leaf litter fungal species belonging to various genera were isolated. A significant variation in microbial number was recorded in different tissues of the plant. Our study revealed that the highest microbial population in these samples was recorded in the litter fungi and the secondhighest number of fungal in the bark was recorded beside the leaves tissues in the study periods. Found in living tissues such as Colletrotrichum, Phomopsis, Phyllosticta, etc. fungal species. But, species richness is high, especially in the case of leaf litter fungi that the number of species is high here and dominant fungi are low due to nutrient deficiency. The nutrient has been in abundance in living tissues; so, widespread in fungal mycelium, the maximum part may be occupied and a few fungi were dominated in their tissues parts. On the contrary, the bark tissues may be less nutrient-rich than the dead tissues, and because the number of microbes within a given range, a few species were more difficult to dominate. But the number of fungal species was higher. Nevertheless, we assume that leaf litter can interact with soil, and saprophytic fungi may be involved in the decomposing process; so, there have been diverse taxa to increase the number of fungi.

\section{ACKNOWLEDGEMENTS}

The first author acknowledge University Grant Commission (UGC) New Delhi for financial support. The authors also thank the staffs of Department of Botany, M.R. Govt. Arts College, Mannargudi for the laboratory facilities and their help and cooperation.

\section{REFERENCES}

1. Mendes R, Garbeva P, Raaijmakers JM. The rhizosphere microbiome: significance of plant beneficial, plant pathogenic, and human pathogenic microorganisms. FEMS Microbiology Reviews. 2013; 37: 634-663.

2. Hirsch GU, Braun U. Communities of parasitic microfungi. In hand book of Vegetation Science (ed. W. Winter hoff) Kluwer, Dordrecht. 1992; 19: 225-250.

3. de Bary A. Morphologie und Physiologie der Pilze, Flechten und Myxomyceten. Engelmann, Leipzig. 1866.

4. Petrini O. Fungal endophytes of tree leaves. In: Microbial Ecology of Leaves (eds. J.A. Andrews and S.S Hirano). Springer- Verlag, New 
York, USA. 1991: 179-197.

5. Schmit JP, Mueller GM. An estimate of the lower limit of global fungal diversity. Biodiversity and Conservation. 2007; 16: 99-111.

6. Danti R, Thomas N, Sieber TN, Sanguineti G. Endophytic mycobiota in bark of European beech (Fagus sylvatica) in the Apennines. Mycological Research. 2002; 106: 1343-1348.

7. Suryanarayanan TS, Rajagopal K. Fungal endophytes (phellophytes) of some tropical forest trees. The Indian Forester. 2000: 126: 165-170.

8. Murali TS, Thirunavukkarasu N, Govindarajulu MB, Suryanarayanan TS. Fungal communities of symptomless barks of tropical trees. Mycosphere. 2013; 4(3): 635- 645.

9. Rayner ADM. Presidential address. Fountains of the forest - the interconnectedness between trees and fungi. Mycological. Research. 1998; 102(12): 1441-1449.

10. Dighton J, White JF, Oudemans P. The fungal community. Its organization and role in the ecosystem. Edited by J.W. Bennett. CRC Press, Boca Raton, Fla. 2005: 1-9.

11. Bills GF, Polishook JD. Abundance and diversity of microfungi in leaf litter of a lowland rain forest in Costa Rica. Mycologia. 1994:187-198.

12. Subramanian CV, Vittal BPR. Studies on litter fungi II. Fungal colonization of Atlantia monophylla Corr. leaves and litter. Nova Hedwigia. 1979; 63: 361-369.

13. Hawkshworth DL. 2001. The magnitude of fungal diversity: the 1.5 million species estimate revisited. Mycology Research. 2001; 105:1422-1432.

14. Arnold AE, Maynard Z, Gilbert G, Coley PD, Kursar TA. 2000. Are tropical endophytic fungi hyper diverse. Ecology Letter. 2000; 3: 267-274.

15. Debdulal B. Endophytic Fungal Diversity in Tropical and Subtropical Plants. Research Journal of Microbiology. 2011; 6: 54-62.

16. Costello MJ, May RM, Stork NE. Can we name Earth's species before they go extinct? Science. 2013; 339: 413-416.

17. Hawksworth DL, Luecking R. Fungal diversity revisited: 2.2 to 3.8 million species. Microbiology Spectrum. 2017; 5(4): FUNK-0052-2016.

18. Paulus BC, Kanowski J, Gadek PA, Hyde KD. Diversity and distribution of saprobic microfungi in leaf litter of an Australian tropical rainforest. 2006; Mycological Research.110: 1441-1454.

19. Suryanarayanan TS, Venkatesan G, Murali TS. Endophytic fungal communities in leaves of tropical forest trees:diversity and distribution patterns. Current Science. 2003; 85: 489-493.

20. Suryanarayanan TS, Devarajan PT, Girivasan KP, Govindarajulu MB, Kumaresan V, Murali TS, Rajamani T, Thirunavukkarasu N, Venkatesan $\mathrm{G}$. The host range of multi-host endophytic fungi. Current Science, 2018; 115(10): 1963-1969.

21. Suryanarayanan T.S, Thirumalai E, Prakash CP, Govinda Rajulu MB, Thirunavukkarasu N. Fungi from two forests of southern India: acomparative study of endophytes, phellophytes and leaf litter fungi. Canadian Journal of Microbiology. 2009; 55: 419-426.

22. Suryanarayanan TS, Kumaresan V, Johnson JA. Foliar fungal endophytes from two species of the mangrove Rhizophora. Canadian Journal of Microbiology.1998; 44, 1003-1006.
23. Fisher PJ, Petrini O, Sutton BC. A comparative study of fungal endophytes in leaves, xylem and bark of Eucalyptus nitens in Australia and England. Sydowia. 1993; 45: 338-345.

24. Frankland JC, Dighton J, Boddy L. Methods for studying fungi in soil and forest litter. In Methods in microbiology: techniques in microbial ecology. Edited by R. Grigorovaand J.R. Norris. Academic Press, London. 1990: 343-404.

25. Hata K, Futai K. Endophytic fungi associated with healthy pine needles and needles infested by the pine needles gall midge, Thecodip/osis japonesis. Canadian Journal of Botany. 1995; 73: 384-390.

26. Taylor LR. Bates, Williams, Hutchinson-a variety of diversities. In: Diversity of insect faunas. Symposia of the Royal EntomologicalSociety of London No. 9.(eds. LA Mound, N Warloff). Blackwell Scientific, Oxford, England. 1978.

27. Ludwig JA, Reynolds JF. Statistical ecology: A primer on methods and computing. John Wiley and Sons, New York, USA. 1988.

28. Hawksworth DL, Luecking R. Fungal diversity revisited: 2.2 to 3.8 million species. Microbiology Spectrum. 2017; 5(4): FUNK-0052-2016.

29. Suryanarayanan TS, Murali TS, Venkatesan G. Occurrence and distributon of fungal endophytes in tropical forests across a rainfall gradient. Canadian Journal of Botany. 2002; 80: 818-826.

30. Photita W, Taylor PWJ, Ford R, Hyde KD. Morphological and molecular characterization of Colletotrichum species from herbaceous plants in Thailand, Fungal Diversity. 2005; 18:117-133.

31. Farr DF, Bills GF, Chumuris GP, Rossman AY. Fungi on Plants and Plant Products in the United States. APS Press, Minnesota, U.S.A. 1989: 816-837

32. Tejesvi MV, Mahesh B, Nalini MS, Prakash HS. Fungal endophyte assemblages from ethnopharmaceutically important medicinal trees. Canadian Journal of Microbiology. 2006; 52: 427-435.

33. Suradkar KP, Hande DV, Kadu SR. Seasonal diversity of endophytic fungi from ten medicinal plants. International Journal of Current Microbiology and Applied Sciences. 2014; 3: 260-265

34. Banerjee D, Manna S, Mahapatra S, Pati BR. Fungal endophytes in three medicinal plants of Lamiaceae. Acta Microbial Immuno Hungariea. 2009; 56: 243-250.

35. Suradkar KP, Hande DV, Kadu SR. Seasonal diversity of endophytic fungi from ten medicinal plants. International Journal of Current Microbiology and Applied Sciences. 2014; 3(9): 260-265.

36. Azevedo JL, Maccheroni W Jr, Pereira JO, de Araújo WL. Endophytic microorganisms: a review on insect control and recent advances on tropical plants. Electronic Journal of Biotechnology. 2000; 3:15-16.

37. Petrini O. Taxonomy of endophytic fungi of aerial plant tissues. In: Microbiology of the phyllosphere (eds. N.J. Fokkema and J.Van den Heuvel), Cambridge University press, Cambridge. 1986: 175-187.

38. Suryanarayanan TS, Thirumalai E, Prakash CP, Govinda Rajulu MB, Thirunavukkarasu N. Fungi from two forests of southern India: acomparative study of endophytes, phellophytes, and leaf litter fungi. Canadian Journal of Microbiology. 2009; 55: 419-426. 